\title{
Removal of Cr (VI) from Simulated and Leachate Wastewaters by Bentonite-Supported Zero-Valent Iron Nanoparticles
}

\author{
Fayuan Wang ${ }^{1, * \mathbb{D}}$, Weiwei Yang ${ }^{1}$, Fangyuan Zheng ${ }^{1}$ and Yuhuan Sun ${ }^{1, *}$ \\ College of Environment and Safety Engineering, Qingdao University of Science and Technology, \\ Qingdao 266042, China; yangww3952@163.com (W.Y.); zhengfy9890@163.com (F.Z.) \\ * Correspondence: wangfayuan@qust.edu.cn (F.W.); yhsun@qust.edu.cn (Y.S.); Tel.: +86-532-8402-2617 (Y.S.)
}

Received: 20 July 2018; Accepted: 27 September 2018; Published: 1 October 2018

\begin{abstract}
Zero-valent iron $\left(\mathrm{Fe}^{0}\right)$ nanoparticles (NPs) have shown excellent ability to remove contaminants hexavalent chromium $(\mathrm{Cr}(\mathrm{VI}))$ from aquatic systems. Use of support materials can help to prevent oxidation and aggregation of $\mathrm{Fe}^{0} \mathrm{NPs}$, and thus enhance their remediation efficiency. However, most previous studies were conducted using artificially synthetic wastewater, and little is known on the remediation effects of supported $\mathrm{Fe}^{0} \mathrm{NPs}$ on actual wastewaters containing $\mathrm{Cr}(\mathrm{VI})$. Here, bentonite-supported $\mathrm{Fe}^{0} \mathrm{NPs}\left(\mathrm{BFe}^{0} \mathrm{NPs}\right)$ with $1-5 \%$ of bentonite were prepared and characterized using scanning electron microscopy (SEM) and X-ray diffraction (XRD) techniques. Batch experiments were performed to study $\mathrm{Cr}(\mathrm{VI})$ removal by the selected $\mathrm{BFe}^{0} \mathrm{NPs}$ from a simulated wastewater and a leachate wastewater originating from a $\mathrm{Cr}$ slag heap-polluted soil. The results show that $\mathrm{Fe}^{0} \mathrm{NPs}$ were uniformly dispersed on the bentonite, leading to a decreased aggregation of NPs, and the optimal mass ratio of bentonite was $4 \%$. Batch experiment results show that lower $\mathrm{pH}$ values favored $\mathrm{Cr}(\mathrm{VI})$ removal by $\mathrm{BFe}^{0} \mathrm{NPs}$. The removal percentage of $\mathrm{Cr}(\mathrm{VI})$ was higher than $90 \%$ for both wastewaters when the $\mathrm{pH}$ value was 2.0, but decreased significantly as $\mathrm{pH}$ value increased. $\mathrm{Cr}(\mathrm{VI})$ removal reaction was quite fast within the initial $10 \mathrm{~min}$, and at least $85 \%$ of $\mathrm{Cr}(\mathrm{VI})$ was removed for both wastewaters. $\mathrm{Cr}(\mathrm{VI})$ removal percentage increased with increasing $\mathrm{BFe}{ }^{0} \mathrm{NPs}$ dosages ranging from 30 to 60 , but remained almost unchanged when the $\mathrm{Fe} / \mathrm{Cr}$ mass ratio increased to above 60 . The reaction of $\mathrm{BFe}^{0} \mathrm{NPs}$ to remove $\mathrm{Cr}(\mathrm{VI})$ followed the pseudo second-order reaction model. In most cases, the removal rates of $\mathrm{Cr}(\mathrm{VI})$ were higher in simulated wastewater than in leachate wastewater, but all approached $100 \%$ at the optimal conditions. Our present results show that $\mathrm{BFe}^{0} \mathrm{NPs}$ with $4 \%$ bentonite are efficient for treatment of $\mathrm{Cr}(\mathrm{VI})$-containing wastewaters.
\end{abstract}

Keywords: bentonite; zero-valent iron; chromium pollution; removal percentage; nanoparticles

\section{Introduction}

The compounds containing chromium $(\mathrm{Cr})$ are among the most common pollutants in soil and groundwater [1,2]. $\mathrm{Cr}(\mathrm{III})$ and $\mathrm{Cr}(\mathrm{VI})$ are two main fractions in $\mathrm{Cr}$-containing compounds. $\mathrm{Cr}(\mathrm{VI})$ is generally more toxic than $\mathrm{Cr}(\mathrm{III})$ for both acute and chronic exposures [3]. $\mathrm{Cr}(\mathrm{VI})$ can enter human bodies via ingestion, inhalation, or even directly from skin and move to organs such as liver, kidney, and lung, inducing genotoxicity, carcinogenicity, mutagenicity, and teratogenicity $[4,5]$. $\mathrm{Cr}(\mathrm{VI})$ compounds have been classified as a class I carcinogen for humans by IARC and listed as one of the priority contaminants [6]. Therefore, effective techniques need to be developed for remediation of $\mathrm{Cr}(\mathrm{VI})$-contaminated soils and groundwater.

Numerous studies have shown that zero-valent iron $\left(\mathrm{Fe}^{0}\right)$ can be used for remediation of pollutants including $\mathrm{Cr}(\mathrm{VI})$ in groundwater and wastewater [7-11]. In recent years, due to the larger specific 
surface area and higher reactivity than common $\mathrm{Fe}^{0}, \mathrm{Fe}^{0}$ nanoparticles (NPs) have shown promising potential in reduction of $\mathrm{Cr}(\mathrm{VI})[8,11]$. However, due to their smaller particles with larger surface energy and intrinsic magnetic interactions, $\mathrm{Fe}^{0} \mathrm{NPs}$ readily become oxidized and agglomerated, leading to a low remediation efficiency. To prevent the agglomeration and oxidation of $\mathrm{Fe}^{0} \mathrm{NPs}$, various support materials have been introduced, such as polymer resin [12], Gum Karaya [13], bentonite [14-16], surfactant-modified zeolite [17], montmorillonite [18], pumice [19], kaolinite [20], sepiolite [21], chitosan [22,23], carbon [24,25], biochar [26-28], humus [29], fly ash-based adsorbent [30], tetraethyl orthosilicate and hexadecyltrimethoxysilane [31], layered double hydroxide [32], graphite [33], titanate nanotube [34], magnetic $\mathrm{Fe}_{3} \mathrm{O}_{4}$ /graphene nanocomposites [35], and reduced graphene oxide-alginate beads [36], most of which have shown enhanced reaction activity and removal rates of $\mathrm{Cr}(\mathrm{VI})$.

Among the studied support materials, bentonite is one of the low-cost and efficient adsorbents. Bentonite is a common clay mineral, consisting mainly of montmorillonite with a high cation exchange capacity and a large specific surface area, and can be used as an efficient adsorbent for removing toxic metals from wastewaters [37]. Bentonite-supported $\mathrm{Fe}^{0} \mathrm{NPs}$ with 1:1 mass ratio of iron and bentonite have been shown to significantly decrease their aggregation and to increase $\mathrm{Fe}^{0} \mathrm{NPs}$ reactivity, thus producing an enhanced $\mathrm{Cr}(\mathrm{VI})$ removal efficiency [16], which also varies with the factors such as initial content of $\mathrm{Cr}(\mathrm{VI}), \mathrm{pH}$, and $\mathrm{BFe}^{0} \mathrm{NPs}$ dose $[14,15]$. However, because of the negative-charged surface of montmorillonite and the oxo-anionic form of hexavalent chromates in wastewater, bentonite generally has a poor ability to adsorb $\mathrm{Cr}(\mathrm{VI})$ from aqueous solution [16]. Therefore, a higher bentonite content may not increase or even inhibit the removal of $\mathrm{Cr}(\mathrm{VI})$ by $\mathrm{BFe}^{0} \mathrm{NPs}$. In addition, most previous studies used artificially simulated $\mathrm{Cr}(\mathrm{VI})$ wastewater, but co-existing ions and organic materials affected $\mathrm{Cr}(\mathrm{VI})$ removal efficiency [38]. Thus far, little is known on whether $\mathrm{Fe}^{0} \mathrm{NPs}$ can effectively remediate actual wastewater and polluted underground water. It is of significance to expand the application fields of $\mathrm{Fe}^{0} \mathrm{NPs}$.

Cr slag pollution poses great environmental risks in China [39]. High levels of $\mathrm{Cr}(\mathrm{VI})$ occur in $\mathrm{Cr}$ slag heap-polluted sites, causing serious pollution to soil, groundwater and surface water. It is of great significance to investigate the use of $\mathrm{Fe}^{0} \mathrm{NPs}$ to remediate $\mathrm{Cr}(\mathrm{VI})$ wastewater. In our current experiments, $\mathrm{BFe}^{0} \mathrm{NPs}$ with $1-5 \%$ bentonite were synthesized and characterized, and both simulated $\mathrm{Cr}(\mathrm{VI})$ wastewater and actual leachate wastewater from a $\mathrm{Cr}$ slag polluted site were used as targets. Our aims are: (1) to study the factors influencing $\mathrm{Cr}(\mathrm{VI})$ removal by $\mathrm{BFe}^{0} \mathrm{NPs}$ with a low bentonite content using batch experiment; and (2) to investigate the utility of $\mathrm{BFe}^{0} \mathrm{NPs}$ for $\mathrm{Cr}(\mathrm{VI})$ removal from simulated and actual $\mathrm{Cr}(\mathrm{VI})$ wastewaters.

\section{Materials and Methods}

\subsection{Materials and Reagents}

The bentonite was primarily sodium montmorillonite (Na-Mt) purchased from Shanghai No. 4 Reagent \& H. V. Chemical Co. Ltd. (Shanghai, China), with a montmorillonite content $>90 \%$. The particle size of the bentonite is $<37 \mu \mathrm{m}$. The composition of the bentonite is $\mathrm{SiO}_{2}(61.64 \%)$, $\mathrm{Al}_{2} \mathrm{O}_{3}(17.08 \%), \mathrm{Fe}_{2} \mathrm{O}_{3}(3.95 \%), \mathrm{CaO}(1.71 \%), \mathrm{MgO}(2.78 \%), \mathrm{K}_{2} \mathrm{O}(0.86 \%)$, and $\mathrm{Na}_{2} \mathrm{O}(4.33 \%) . \mathrm{FeSO}_{4}$ and $\mathrm{NaBH}_{4}$ were purchased from Sinopharm Chemical Reagent Co. Ltd. (Shanghai, China). $\mathrm{K}_{2} \mathrm{Cr}_{2} \mathrm{O}_{7}$ was purchased from Tianjin Standard Technology Co. Ltd. (Tianjin, China). All chemicals were analytical-reagent grade.

\subsection{Synthesis of $B F e^{0} N P s$}

Briefly, $5.56 \mathrm{~g} \mathrm{FeSO}_{4} \cdot 7 \mathrm{H}_{2} \mathrm{O}$ was added into a $250 \mathrm{~mL}$ conical flask with $100 \mathrm{~mL}$ distilled water, and stirred with a magnetic stirrer until all powder was dissolved. A certain quantity of bentonite was added to the above solution to obtain $\mathrm{BFe} \mathrm{e}^{0} \mathrm{NPs}$ with different percentages of bentonite. After stirring for $30 \mathrm{~min}$ with a magnetic stirrer, the mixture was centrifuged at 10,000 rpm, and the precipitated solids were separated and transferred to $250 \mathrm{~mL}$ conical flasks. $\mathrm{NaBH}_{4}$ solution prepared by dissolving 
$1.5 \mathrm{~g} \mathrm{NaBH}_{4}$ in $50 \mathrm{~mL}$ of deionized water was added dropwise into the flasks. Black solid $\mathrm{Fe}^{0}$ particles were observed immediately after the first drop of $\mathrm{NaBH}_{4}$ solution was added. After all the $\mathrm{NaBH}_{4}$ solution was added, the mixture was kept for another $30 \mathrm{~min}$ of stirring. The reduction between iron and borohydride can be indicated with the following reaction:

$$
4 \mathrm{Fe}^{2+}+3 \mathrm{BH}_{4}{ }^{-}+9 \mathrm{H}_{2} \mathrm{O} \rightarrow 4 \mathrm{Fe}^{0}+3 \mathrm{H}_{2} \mathrm{BO}_{3}{ }^{-}+8 \mathrm{H}^{+}+8 \mathrm{H}_{2}
$$

The solid particles were separated magnetically, and quickly washed triple times with pure ethanol, and then oven-dried at $60{ }^{\circ} \mathrm{C}$ overnight. Through changing the mass ratio, the BFe ${ }^{0} \mathrm{NPs}$ with bentonite at $1 \%, 2 \%, 3 \%, 4 \%$, and $5 \%$ were synthesized following the same procedure. Pre-experiments have found that $\mathrm{BFe}^{0} \mathrm{NPs}$ with a bentonite content of $4 \%$ has the largest removal percentage of $\mathrm{Cr}(\mathrm{VI})$ from wastewater, and thus they were selected in the following batch experiments.

\subsection{Characterizations and Measurements}

To characterize the overall size distribution and morphology of $\mathrm{BFe}^{0} \mathrm{NPs}$, scanning electron microscope (SEM) (6700F, JEOL, Tokyo, Japan) equipped with X-ray energy dispersive spectrometer (EDS) was used. SEM images were taken at different magnifications at an operating voltage of $30 \mathrm{kV}$.

Characterization of $\mathrm{BFe}^{0} \mathrm{NPs}$ was performed using an X-ray diffractometer (XRD, Rigaku $\mathrm{D} / \mathrm{max}-2500 \mathrm{PC}$, Rigaku Industrial Corp., Tokyo, Japan), operating with $\mathrm{Cu} \mathrm{K} \alpha$ radiation at $40 \mathrm{kV}$ and $150 \mathrm{~mA}$, scanning over the range $5^{\circ}-90^{\circ}$ in $2 \theta$, step size $0.02^{\circ}$.

The concentration $\mathrm{Cr}$ (VI) in solution was detected using the 1,5-diphenylcarbazide method with a visible spectrophotometer (TAS-986, Shanghai Lengguang Technology Co. Ltd., Shanghai, China).

\subsection{Simulated Wastewater and Actual Wastewater}

Simulated wastewater containing $50 \mathrm{mg} / \mathrm{L} \mathrm{Cr}(\mathrm{VI})$ was obtained by dissolving $\mathrm{K}_{2} \mathrm{Cr}_{2} \mathrm{O}_{7}$ in deionized water. Cr-polluted soil was collected from a $\mathrm{Cr}$ slag heap site at Qingdao Hongxing Chemical Co. Ltd. (Qingdao, China). To investigate the applicability to remove $\mathrm{Cr}(\mathrm{VI})$ from actual wastewater, the leachate was prepared by washing $200 \mathrm{~g}$ Cr-polluted soil using $800 \mathrm{~mL} 0.5 \mathrm{M} \mathrm{HCl}$. The wastewater was centrifuged and then filtered, with the following characteristics, $\mathrm{pH}$ 2.1, $\mathrm{Cr}(\mathrm{VI})$ $52.89 \mathrm{mg} / \mathrm{L}$, Fe $586.19 \mathrm{mg} / \mathrm{L}, \mathrm{Mn} 49.01 \mathrm{mg} / \mathrm{L}, \mathrm{Ca} 1544.09 \mathrm{mg} / \mathrm{L}$, and Mg $239.30 \mathrm{mg} / \mathrm{L}$.

\subsection{Batch Experiments}

Batch experiments were conducted at room temperature $\left(25^{\circ} \mathrm{C}\right)$ on a mechanical shaker at $120 \mathrm{rpm}$ using $100 \mathrm{~mL}$ conical flasks. The wastewater was sampled after shaking and filtered through $0.45 \mu \mathrm{m}$ filter membrane for analysis of $\mathrm{Cr}(\mathrm{VI})$.

\subsubsection{Effect of the $\mathrm{pH}$ Value}

The $\mathrm{pH}$ values of $\mathrm{Cr}(\mathrm{VI})$ wastewater were adjusted with $\mathrm{HCl}(0.1 \mathrm{M})$ or $\mathrm{NaOH}(0.1 \mathrm{M})$ solutions. Then, $60 \mathrm{mg} \mathrm{BFe} \mathrm{NPs}^{0}$ were added into the flasks with $20 \mathrm{~mL}$ simulated or actual wastewaters, and then agitated at $25^{\circ} \mathrm{C}$ for $2 \mathrm{~h}$ at $120 \mathrm{rpm}$.

\subsubsection{Effect of Reaction Time}

The second experiment was to determine the impact of reaction time and equilibrium time. The $\mathrm{pH}$ of $\mathrm{Cr}(\mathrm{VI})$ wastewater was adjusted to 2.0, 2.5, and 3.0, respectively. Wastewater $(20 \mathrm{~mL})$ and $60 \mathrm{mg} \mathrm{BFe}{ }^{0} \mathrm{NPs}$ were added into the flasks and then agitated at $120 \mathrm{rpm}$ for reaction times ranging from 10 to $180 \mathrm{~min}$. Samples were taken at 10, 20, 30, 45, 60, 90, 120, and $180 \mathrm{~min}$, respectively. 


\subsubsection{Effect of $\mathrm{BFe}^{0} \mathrm{NPs}$ Dosage}

$\mathrm{BFe}^{0} \mathrm{NPs}$ at different doses, i.e., 30, 45, 50, 60, 70, 100, and $150 \mathrm{mg}$, were added into the flasks containing $20 \mathrm{~mL}$ simulated or actual wastewaters at $\mathrm{pH} 2.0$, and then agitated at $25^{\circ} \mathrm{C}$ for $2 \mathrm{~h}$ at $120 \mathrm{rpm}$.

\subsection{Calculation of Removal Percentage and Removal Capacity}

$\mathrm{Cr}(\mathrm{VI})$ removal percentage $(\%)$, the capacity of $\mathrm{Cr}(\mathrm{VI})$ removal per unit mass of $\mathrm{BFe}^{0} \mathrm{NPs}$ at time $t$ $\left(q_{\mathrm{t}}, \mathrm{mg} / \mathrm{g}\right)$, and the capacity of $\mathrm{Cr}(\mathrm{VI})$ removal per unit mass of $\mathrm{BFe}^{0} \mathrm{NPs}$ at equilibrium $\left(q_{\mathrm{e}}, \mathrm{mg} / \mathrm{g}\right)$, were calculated from the following equations [40]:

$$
\begin{gathered}
\mathrm{Cr}(\mathrm{VI}) \text { removal percentage }=\frac{C_{0}-C_{\mathrm{e}}}{C_{0}} \times 100 \\
q \mathrm{t}=\mathrm{V} \times \frac{C_{0}-C_{\mathrm{t}}}{m_{\mathrm{s}}} \\
q \mathrm{e}=\mathrm{V} \times \frac{C_{0}-C_{\mathrm{e}}}{m_{\mathrm{s}}}
\end{gathered}
$$

where $C_{0}$ and $C_{\mathrm{e}}(\mathrm{mg} / \mathrm{L})$ are the initial and the final $\mathrm{Cr}(\mathrm{VI})$ concentrations in the wastewaters in flasks, respectively, and $C_{\mathrm{t}}(\mathrm{mg} / \mathrm{L})$ is the $\mathrm{Cr}(\mathrm{VI})$ concentrations at time $t . \mathrm{V}$ is the volume of wastewater $(\mathrm{L})$ and $m_{\mathrm{s}}$ is the mass of $\mathrm{BFe}^{0} \mathrm{NPs}$ added $(\mathrm{g})$.

\subsection{Kinetics of $\mathrm{Cr}(\mathrm{VI})$ Removal by $B F e^{0} N P s$}

The kinetics of $\mathrm{Cr}(\mathrm{VI})$ were tested using pseudo-second-order sorption equation [40]:

$$
\frac{t}{q t}=\frac{1}{k q e^{2}}+\frac{t}{q e}
$$

where $k\left[\mathrm{mg} \cdot(\mathrm{mg} \cdot \mathrm{min})^{-1}\right]$ is the rate constant of the pseudo-second-order reaction.

\subsection{Data Analysis}

The nanoparticle size distribution of $\mathrm{Fe}^{0}$ was determined by Nano Measurer 1.2 software (Beijing Zhongke Baice Technology Service Co. Ltd., Beijing, China). The XRD data were analyzed using Jade 7.1.2 software (Jade Software Corp., Christchurch, New Zealand). The data were processed with Excel 2010 (Microsoft Corp., Redmond, WA, USA) and Origin 6.0 software (OriginLab, Northampton, MA, USA). Means with standard deviations of $\mathrm{Cr}(\mathrm{VI})$ removal percentage, $q_{\mathrm{t}}$, and $q_{\mathrm{e}}$ were calculated. Linear regression analysis was performed to calculate reaction kinetics and the reaction rate constant.

\section{Results and Discussion}

\subsection{Characterization of $B F e^{0} N P s$}

The morphology of bentonite and distribution of $\mathrm{Fe}^{0} \mathrm{NPs}$ on bentonite were investigated using SEM (Figure 1). The pure bentonite displayed an anomalous layer structure with a relatively smooth surface. When loaded on the bentonite, $\mathrm{Fe}^{0} \mathrm{NPs}$ were found to disperse on the surface and edges of bentonite (Figure $1 \mathrm{~b}-\mathrm{f}$ ). The particle size of $\mathrm{Fe}^{0} \mathrm{NPs}$ dispersed on bentonite varied in the range 50-120 nm, with an average of about $77 \mathrm{~nm}$. Some $\mathrm{Fe}^{0} \mathrm{NPs}$ on the bentonite appeared to aggregate into chain-like conformations, however, the degree of aggregation decreased with the increase of the mass ratio of bentonite, and the $\mathrm{BFe}^{0} \mathrm{NPs}$ with $4 \%$ and $5 \%$ of bentonite appeared to have less chain-like conformations than other $\mathrm{BFe}^{0} \mathrm{NPs}$ with less bentonite. The aggregated proportion of $\mathrm{Fe}^{0} \mathrm{NPs}$ tended to decline as the Fe(II) precursor concentration decreased [14,16]. 

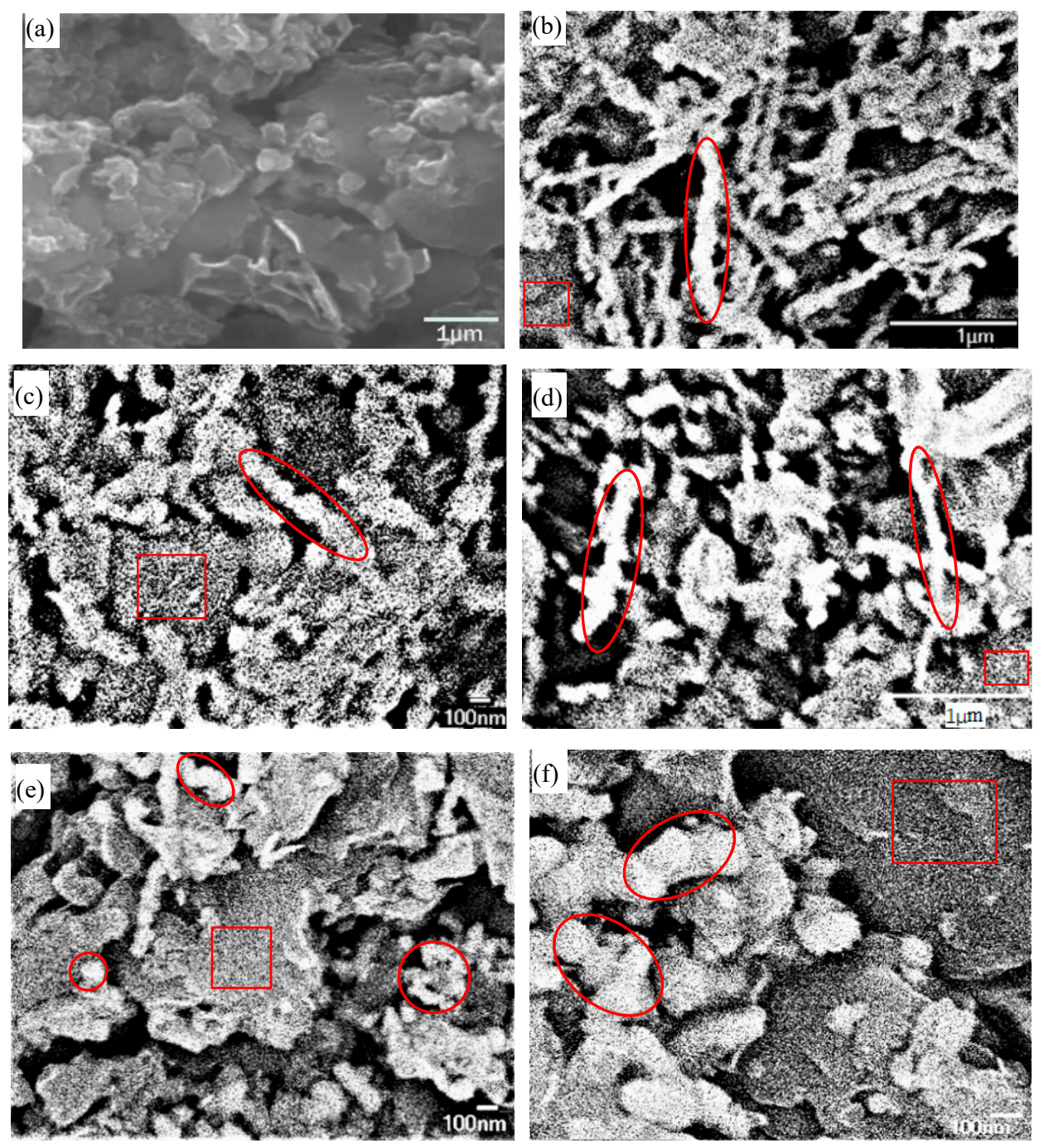

Figure 1. SEM images of bentonite (a) and $\mathrm{BFe}^{0} \mathrm{NPs}$ with different bentonite contents (b-f): (a) bentonite; (b) $1 \%$; (c) 2\%; (d) 3\%; (e) 4\%; and (f) 5\%. The white chain-like conformations and dispersed particles represent $\mathrm{Fe}^{0}$ (circles/ovals), and the grey backgrounds represent bentonite (rectangles).

Using a bentonite/iron mass ratio of 1:1, Shi et al. [14,16] also found decreased aggregation of $\mathrm{Fe}^{0}$ particles on the bentonite. Bentonite generally shows a poor adsorption capacity for $\mathrm{Cr}(\mathrm{VI})$-containing compounds [16]. Hence, $\mathrm{Cr}(\mathrm{VI})$ removal by $\mathrm{BFe}^{0} \mathrm{NPs}$ is mainly attributed to the reduction capacity of $\mathrm{Fe}^{0}$. Our results show that $4 \%$ of bentonite is effective to reduce aggregation of $\mathrm{Fe}^{0} \mathrm{NPs}$ and to enhance the stability of $\mathrm{Fe}^{0} \mathrm{NPs}$. A comparison pre-experiment confirmed $\mathrm{BFe}^{0} \mathrm{NPs}$ with $4 \%$ of bentonite had the highest $\mathrm{Cr}(\mathrm{VI})$ removal capacity (data not shown).

The XRD patterns of $\mathrm{BFe}^{0} \mathrm{NPs}$ with different bentonite contents showed a number of peaks. The largest peak $\left(2 \theta=26.67^{\circ}\right)$ and other smaller peaks stem from the internal structures of bentonite (Figure 2). The characteristic peaks of $\mathrm{Fe}^{0}\left(2 \theta=45.8^{\circ}\right)$ were observed, which was stronger in $\mathrm{BFe}^{0} \mathrm{NPs}$ with $4 \%$ bentonite than in $\mathrm{BFe}^{0} \mathrm{NPs}$ with other contents of bentonite (Figure 2). When the bentonite content is $5 \%$, more $\mathrm{Fe}^{0} \mathrm{NPs}$ may enter into the inner layer of bentonite, thus leading to a weak peak. This confirms the mass ratio of Fe and bentonite influences the dispersity and stability of $\mathrm{Fe}^{0}$ in the NPs. An optimal mass ratio should be selected to ensure not only the "support" role of bentonite, but also the reactivity of $\mathrm{Fe}^{0}$. 


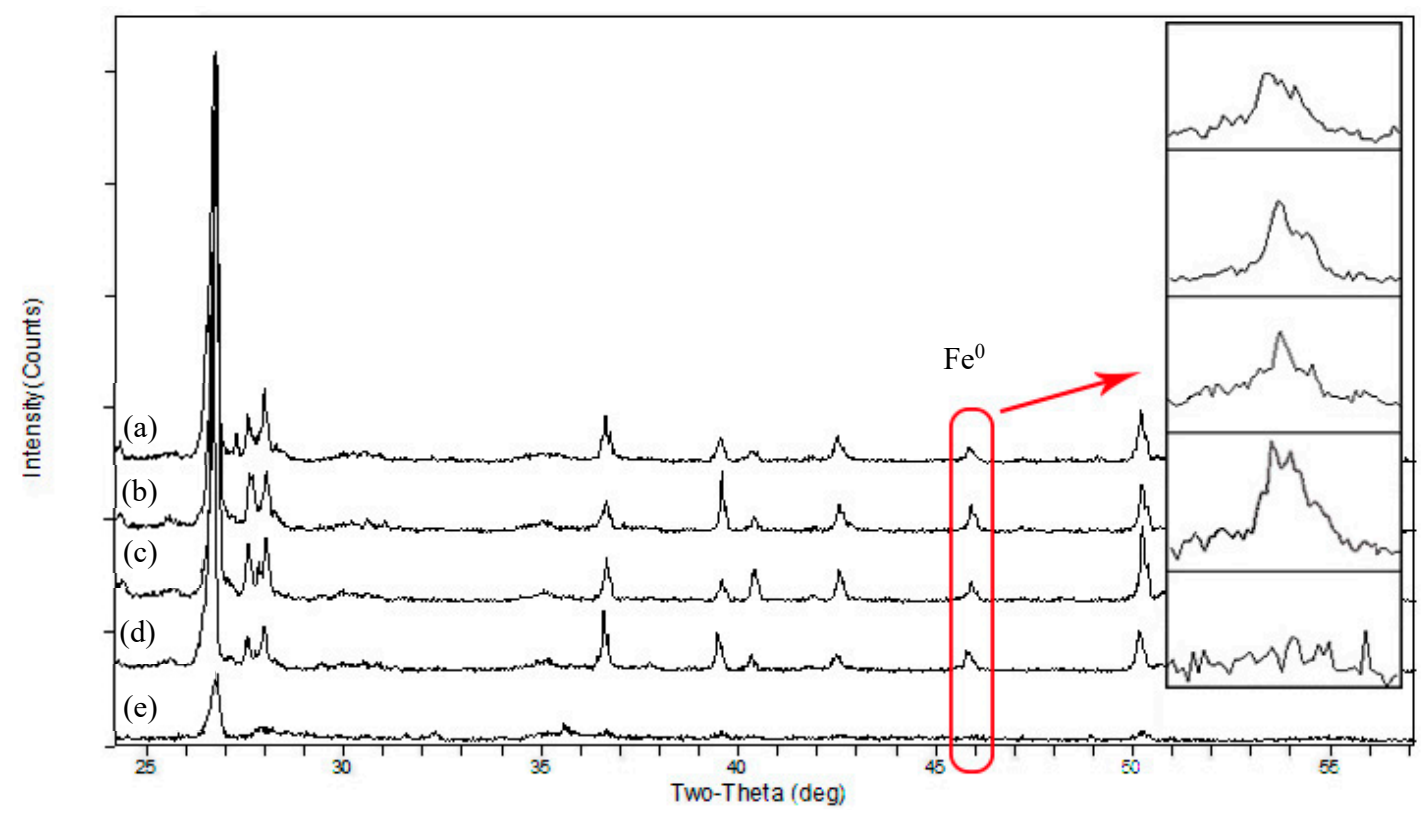

Figure 2. XRD characterization of $\mathrm{BFe}^{0} \mathrm{NPs}$ with different bentonite contents: (a) $1 \%$; (b) $2 \%$; (c) $3 \%$; (d) $4 \%$; and (e) $5 \%$.

\subsection{Factors Influencing Cr(VI) Removal}

\subsubsection{Effect of Wastewater $\mathrm{pH}$}

The solution $\mathrm{pH}$ is among the most significant factors that determine both the forms of metal ion and the surface characteristics of the adsorbent in the solution [20]. In aquatic solution, $\mathrm{Cr}$ (VI) occurs mainly as $\mathrm{HCrO}_{4}{ }^{-}$or $\mathrm{Cr}_{2} \mathrm{O}_{7}{ }^{2-}$ at $\mathrm{pH} 1.0$ to 6.0, and as $\mathrm{CrO}_{4}{ }^{2-}$ over $\mathrm{pH} 6.0$ [2]. A previous study has shown that $\mathrm{Cr}(\mathrm{VI})$ removal rate reached $100 \%$ within $1 \mathrm{~min}$ at $\mathrm{pH} 2.0$, but was lower than $30 \%$ at $\mathrm{pH} 8.0$ [14]. Here, simulated wastewater was adjusted to $\mathrm{pH} 2.0-10.0$, while leachate wastewater was adjusted to $\mathrm{pH} 2.0-6.0$ based on the results obtained from simulated wastewater. Our results show similar conclusions that $\mathrm{Cr}(\mathrm{VI})$ removal decreased sharply from $100 \%$ to $60 \%$ for simulated wastewater and from $90 \%$ to $28 \%$ for leachate wastewater when the $\mathrm{pH}$ increased from 2.0 to 3.0 (Figure 3). At $\mathrm{pH} 6.0$, only $50 \%$ of $\mathrm{Cr}(\mathrm{VI})$ was removed from simulated wastewater and $10 \%$ from leachate wastewater. At $\mathrm{pH} 8.0,45 \%$ of $\mathrm{Cr}(\mathrm{VI})$ was removed from simulated wastewater, higher than that reported by Shi et al. [14], which can be attributed to the higher content of $\mathrm{Fe}^{0}$ in the $\mathrm{BFe}^{0} \mathrm{NPs}$.

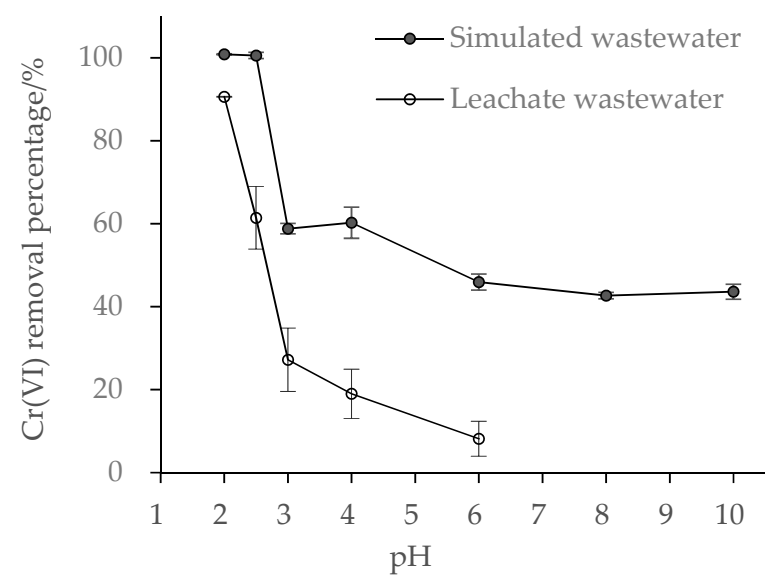

Figure 3. Effect of initial $\mathrm{pH}$ values on $\mathrm{Cr}(\mathrm{VI})$ removal $(n=3)$ from wastewaters by $\mathrm{BFe}^{0} \mathrm{NPs}(4 \%)$. 
Our findings confirm the similar conclusion obtained by Shi et al. [14] that acidic $\mathrm{pH}$ enhanced $\mathrm{Cr}(\mathrm{VI})$ removal. At lower $\mathrm{pH}$, both $\mathrm{HCrO}_{4}{ }^{-}$and $\mathrm{Cr}_{2} \mathrm{O}_{7}{ }^{2-}$ anions are strong oxidizers with high redox potentials, whilst $\mathrm{CrO}_{4}{ }^{2-}$ anion existing at high $\mathrm{pH}$ has only a weak oxidizing capacity [9]. Apparently, redox reaction occurs more readily between $\mathrm{Fe}^{0} \mathrm{NPs}$ and $\mathrm{Cr}(\mathrm{VI})$ at lower $\mathrm{pH}$. Another possible reason is a lower $\mathrm{pH}$ accelerates the corrosion of $\mathrm{Fe}^{0} \mathrm{NPs}$, and $\mathrm{Cr}(\mathrm{III})$ and $\mathrm{Fe}(\mathrm{III})$ hydroxides cannot easily precipitate on the NPs surfaces, thus leading to an increased reaction rate [41]. However, at a higher $\mathrm{pH}$, co-precipitates of $\mathrm{Cr}(\mathrm{IIII})$ and $\mathrm{Fe}(\mathrm{III})$ on the surface of $\mathrm{BFe}^{0} \mathrm{NPs}$ may hinder the reduction of $\mathrm{Cr}(\mathrm{VI})$ by $\mathrm{Fe}^{0}$. Furthermore, increased $\mathrm{H}^{+}$will neutralize the negative charge on the surface of bentonite and reduce the electrostatic repulsion against anionic $\mathrm{Cr}(\mathrm{VI})$. This consequently leads to enhanced redox reaction of $\mathrm{Fe}^{0}$ and $\mathrm{Cr}(\mathrm{VI})$ [42].

Another finding is that $\mathrm{Cr}(\mathrm{VI})$ removal percentage was always lower in leachate wastewater than in simulated wastewater (Figure 3). $\mathrm{Cr}(\mathrm{VI})$ reduction by $\mathrm{Fe}^{0}$ varies with experimental conditions including solution composition [9]. Previous studies have shown that the remediation effects of $\mathrm{Fe}^{0}$ are positively or negatively influenced by co-existing ions such as anionic $\mathrm{PO}_{4}{ }^{3-}, \mathrm{SiO}_{3}{ }^{2-}, \mathrm{SO}_{4}{ }^{2-}$, $\mathrm{NO}_{3}{ }^{-}, \mathrm{HCO}_{3}{ }^{-}$, and $\mathrm{Cl}^{-}$; cationic $\mathrm{Ca}^{2+}, \mathrm{Mg}^{2+}, \mathrm{Na}^{+}, \mathrm{Zn}^{2+}, \mathrm{Cu}^{2+}$, and $\mathrm{Cd}^{2+}$; and natural organic matter [38,43-45]. For example, most of the anions especially $\mathrm{HCO}_{3}{ }^{-}$significantly suppressed $\mathrm{Cr}(\mathrm{VI})$ removal, but cations and natural organic matter enhanced the removal [38]. In Cr(VI)-polluted soil, humic acid facilitated the reduction of $\mathrm{Cr}(\mathrm{VI})$ [46]. In our experiments, simulated wastewater was pure solution of $\mathrm{K}_{2} \mathrm{Cr}_{2} \mathrm{O}_{7}$, while leachate wastewater originated from $\mathrm{Cr}$-polluted soil containing more complex components in addition to $\mathrm{Cr}(\mathrm{VI})$, such as $\mathrm{Fe}^{3+}, \mathrm{Mn}^{2+}, \mathrm{Ca}^{2+}, \mathrm{Mg}^{2+}$, other soluble anions, and natural organic matters. These materials especially oxidized ions may compete with $\mathrm{Cr}(\mathrm{VI})$ for reaction with $\mathrm{Fe}^{0}$, and occupy the adsorption sites on the surface of bentonite, thus resulting in a lower $\mathrm{Cr}(\mathrm{VI})$ removal percentage.

However, this finding differs from a previous study that $100 \%$ of total $\mathrm{Cr}$ was removed by $\mathrm{BFe} \mathrm{N}^{0} \mathrm{NPs}$ from an electroplating wastewater, and the concomitant ions $\mathrm{Cu}, \mathrm{Pb}$, and $\mathrm{Zn}$ did not impact $\mathrm{Cr}$ removal percentage [14]. Electroplating wastewaters are generally high in heavy metals, such as $\mathrm{Cr}(\mathrm{VI}), \mathrm{Pb}^{2+}$, $\mathrm{Cu}^{2+}$, and $\mathrm{Zn}^{2+}$, but low in organic matter, while in our present study, leachate wastewater may contain different reductive materials such as dissolved organic matter, in addition to $\mathrm{Mn}^{2+}$, which may explain the lower $\mathrm{Cr}(\mathrm{VI})$ reduction by $\mathrm{BFe}^{0} \mathrm{NPs}$.

\subsubsection{Effect of Reaction Time}

Figure 4 shows $\mathrm{Cr}(\mathrm{VI})$ removal percentages of two wastewaters at $\mathrm{pH} 2.0$ varying with different reaction times. Similarly, as shown in Figure 3, Cr(VI) removal percentages were lower in leachate wastewater than in simulated wastewater. However, $\mathrm{Cr}(\mathrm{VI})$ removal was very fast initially for both two wastewaters; about $85 \%$ of $\mathrm{Cr}(\mathrm{VI})$ was removed from simulated wastewater within $10 \mathrm{~min}$, and $\mathrm{Cr}(\mathrm{VI})$ was completely removed within $60 \mathrm{~min}$, indicating an equilibrium time of $60 \mathrm{~min}$ at $\mathrm{pH}$ 2.0. For leachate wastewater, $\mathrm{Cr}(\mathrm{VI})$ removal percentage reached $90 \%$ within the initial $10 \mathrm{~min}$, and maintained at about $90 \%$ thereafter. However, at $\mathrm{pH} 2.5$ and 3.0, equilibrium times increased to $120 \mathrm{~min}$, and $\mathrm{Cr}(\mathrm{VI})$ removal percentages decreased significantly especially for leachate wastewater. 

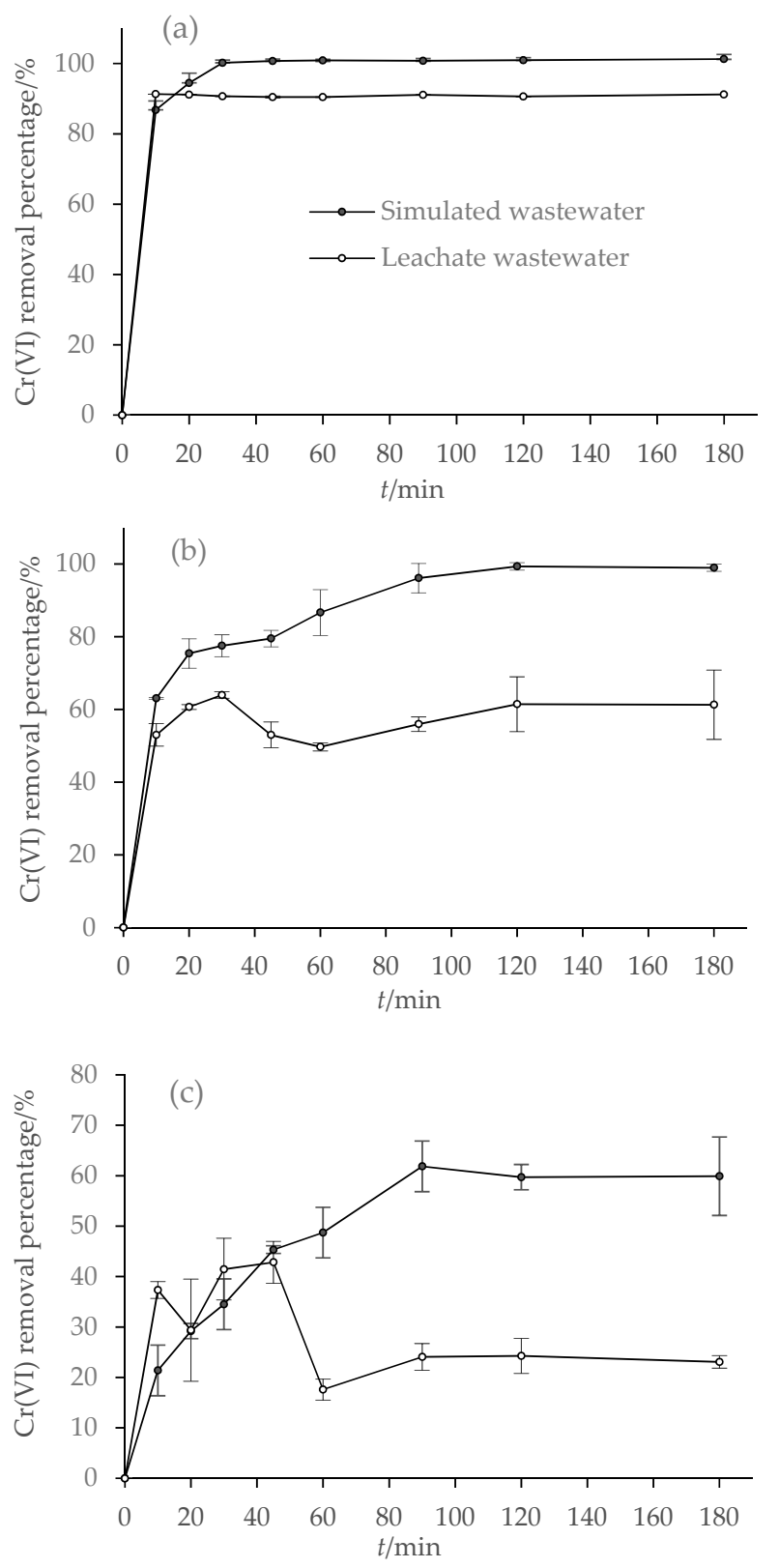

Figure 4. Effect of reaction time on $\mathrm{Cr}(\mathrm{VI})$ removal $(n=3)$ from wastewaters by $\mathrm{BFe}^{0} \mathrm{NPs}(4 \%)$ at different $\mathrm{pH}$ values: (a) $\mathrm{pH}$ 2.0; (b) $\mathrm{pH} 2.5$; and (c) $\mathrm{pH} 3.0$.

The high $\mathrm{Cr}(\mathrm{VI})$ removal and short equilibrium time confirm that bentonite was effective to maintain dispersity and activity of $\mathrm{Fe}^{0}$ particles. Obviously, at the initial stage, redox reaction was fast because of the abundance of $\mathrm{Cr}(\mathrm{VI})$ and active $\mathrm{Fe}^{0}$ particles. As reaction time prolonged, the amount of active $\mathrm{Fe}^{0} \mathrm{NPs}$ became less, and, thus, the redox reaction became more difficult. In addition, precipitations of reaction products such as $\mathrm{Cr}$ (III) and Fe(III) may also occupy the active sites of $\mathrm{BFe}^{0} \mathrm{NPs}$ and hinder the redox reaction [41].

As shown in Figure 4, Cr(VI) removal increased sharply within the first $10 \mathrm{~min}$, and then rose slightly or even decreased in the later reaction process, suggesting the removal of $\mathrm{Cr}(\mathrm{VI})$ by $\mathrm{BFe}^{0} \mathrm{NPs}$ is more than a simple chemical reaction $[9,14]$. Previous studies have shown that other physical reactions such as adsorption phase probably occur $[12,14,47]$. In our current experiment, a physical mechanism such as reversible adsorption may also occur, especially before reaching equilibrium. Furthermore, co-existing materials in leachate wastewater may disturb $\mathrm{Cr}(\mathrm{VI})$ reduction or compete with the 
adsorption of $\mathrm{Cr}(\mathrm{VI})$. The different trends for $\mathrm{Cr}(\mathrm{VI})$ removal from the two wastewaters suggest that the overall mechanisms are much complicated in leachate wastewater than in simulated wastewater.

\subsubsection{Effect of $\mathrm{BFe}^{0} \mathrm{NPs}$ Dosage}

The Cr (VI) removal from simulated wastewater increased rapidly as the $\mathrm{BFe}^{0} \mathrm{NPs}$ dosage increased from 30-40 $\mathrm{mg}$, and slowly from $40-60 \mathrm{mg}$, but remained almost unchanged ranging from 60 to $150 \mathrm{mg}$ (Figure 5). Comparatively, $\mathrm{Cr}(\mathrm{VI})$ removal from leachate wastewater increased dramatically as the $\mathrm{BFe}^{0} \mathrm{NPs}$ dosage increased from 30 to $60 \mathrm{mg}$, and thereafter, increased slowly from 60 to $150 \mathrm{mg}$. Obviously, the increase in $\mathrm{Cr}(\mathrm{VI})$ removal with increasing $\mathrm{BFe}^{0} \mathrm{NPs}$ dosage can be attributed to the increased active sites, where the reduction takes place $[23,42]$. When the $\mathrm{BFe}^{0} \mathrm{NPs}$ reach an equilibrium dosage providing enough reactive sites for $\mathrm{Cr}(\mathrm{VI})$ reduction, $\mathrm{Cr}(\mathrm{VI})$ removal will maintain constant, and not increase with the increasing dosage of $\mathrm{BFe}^{0} \mathrm{NPs}$.

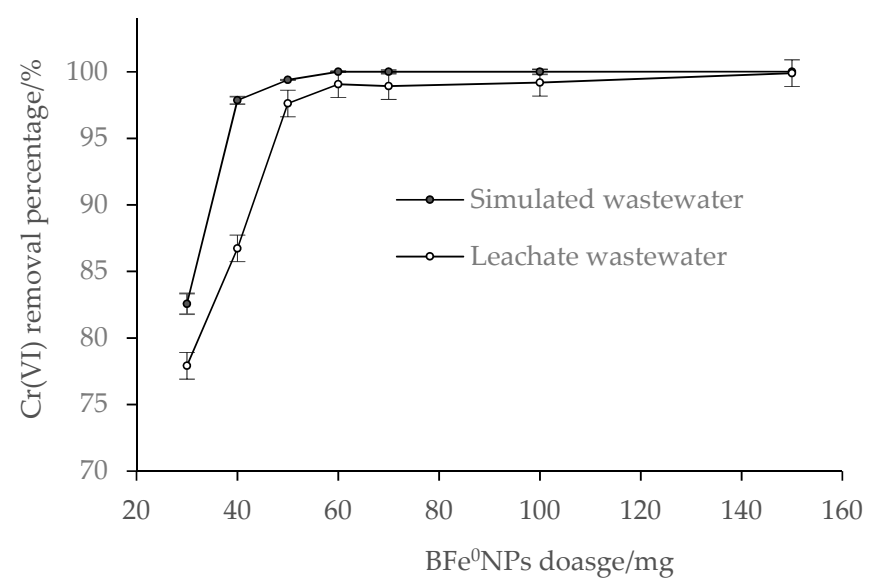

Figure 5. Effect of $\mathrm{BFe}^{0} \mathrm{NPs}(4 \%)$ dosage on $\mathrm{Cr}(\mathrm{VI})$ removal $(n=3)$ from wastewaters.

Overall, $\mathrm{Cr}(\mathrm{VI})$ removal percentage was lower in simulated wastewater than in leachate wastewater, especially at the low dosage of $\mathrm{BFe}^{0} \mathrm{NPs}$, but the difference became less with the increase of $\mathrm{BFe}^{0} \mathrm{NPs}$ dosage, and no difference was observed when $150 \mathrm{mg}$ BFe0NPs were added. This can be attributed to the co-existing materials in leachate wastewater competing with $\mathrm{Cr}(\mathrm{VI})$ for active sites in $\mathrm{Fe}^{0} \mathrm{NPs}$ and/or adsorption sites in bentonite. When $\mathrm{BFe}^{0} \mathrm{NPs}$ dosage was high enough, the impacts of the co-exiting materials were offset, and therefore nearly $100 \%$ of $\mathrm{Cr}(\mathrm{VI})$ was removed from leachate wastewater.

In Figure 5, a dosage of $60 \mathrm{mg} \mathrm{BFe}{ }^{0} \mathrm{NPs}$ may be effective and economic for their actual application in remediation of $\mathrm{Cr}(\mathrm{VI})$ wastewater. Regardless of the cost, a higher dosage may cause aggregation of $\mathrm{BFe}^{0} \mathrm{NPs}$, thus leading to a lower reaction efficiency and $\mathrm{Cr}(\mathrm{VI})$ removal capacity.

\subsection{Reaction Kinetics}

The reaction kinetics were investigated using wastewaters at different $\mathrm{pH}$ values in the reaction time of $180 \mathrm{~min}$. Kinetic parameters including second order rate constant $k$, experimental equilibrium removal capacity $q_{\mathrm{e}, \exp }$, calculated equilibrium removal capacity $q_{\mathrm{e}, \mathrm{cal}}$, and regression coefficients $\left(R^{2}\right)$, are shown in Table 1. The $q_{\mathrm{e}, \text { cal }}$ values using the pseudo second-order model are in good accordance with the experimental values $\left(q_{\mathrm{e}, \mathrm{exp}}\right)$. The $R^{2}$ values range from 0.9416 to 1 , indicating that the system under study well fits the pseudo-second-order model (Figure 6). The good consistency between $q_{\mathrm{e}, \text { cal }}$ and $q_{\mathrm{e}, \exp }$, together with the large $R^{2}$ values, suggests the reaction process may involve in a chemical sorption [48], or valency forces through sharing or the electron exchange between $\mathrm{Cr}(\mathrm{VI})$ and $\mathrm{BFe}^{0} \mathrm{NPs}$ as covalent forces [49]. 
Table 1. Pseudo second-order kinetic parameters for $\mathrm{Cr}(\mathrm{VI})$ removal from two wastewaters by $\mathrm{BFe}^{0} \mathrm{NPs}$ $(4 \%)$ at different $\mathrm{pH}$ values.

\begin{tabular}{|c|c|c|c|c|c|c|c|c|}
\hline \multirow{2}{*}{ pH } & \multicolumn{4}{|c|}{ Simulated Wastewater } & \multicolumn{4}{|c|}{ Leachate Wastewater } \\
\hline & $q_{\mathrm{e}, \mathrm{exp}} / \mathrm{mg} \cdot \mathrm{g}^{-1}$ & $q_{\mathrm{e}, \mathrm{cal}} / \mathrm{mg} \cdot \mathrm{g}^{-1}$ & $k / g(m g \cdot \min )^{-1}$ & $R^{2}$ & $q_{\mathrm{e}, \mathrm{exp}} / \mathrm{mg} \cdot \mathrm{g}^{-1}$ & $q_{e, c a l} / \mathrm{mg} \cdot \mathrm{g}^{-1}$ & $k / g(m g \cdot \min )^{-1}$ & $R^{2}$ \\
\hline 2.0 & 6.65 & 6.65 & 1.45 & 1 & 5.80 & 5.79 & 0.30 & 1 \\
\hline 2.5 & 6.45 & 6.60 & 0.01 & 0.9907 & 4.68 & 4.48 & 0.06 & 0.9961 \\
\hline 3.0 & 2.14 & 2.51 & 0.04 & 0.9416 & 2.55 & 2.45 & -0.07 & 0.9664 \\
\hline
\end{tabular}
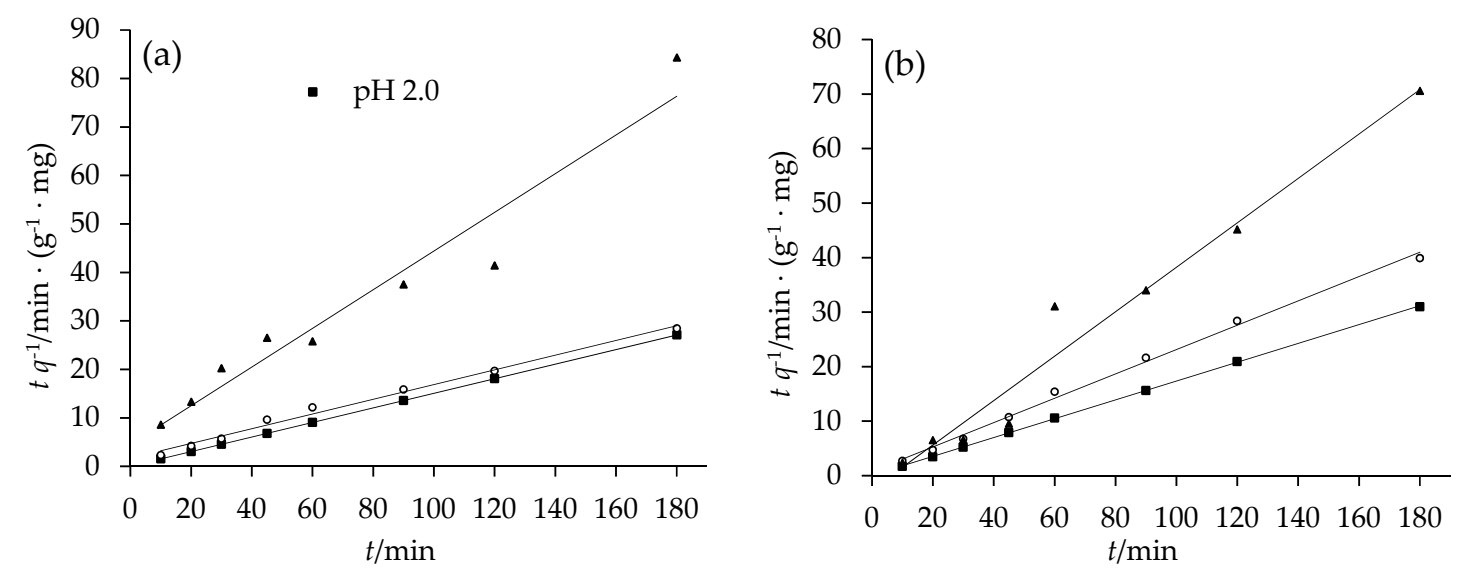

Figure 6. Pseudo second-order model for $\mathrm{Cr}(\mathrm{VI})$ removal by $\mathrm{BFe}^{0} \mathrm{NPs}(4 \%)$ at different $\mathrm{pH}$ values: (a) simulated wastewater; and (b) leachate wastewater.

Through comparing $q_{\mathrm{e}, \mathrm{cal}}$ and $q_{\mathrm{e}, \mathrm{exp}}$, and $R^{2}$ values at different $\mathrm{pH}$ values, our present results confirm the above-mentioned result (see Section 3.2.1) that acidic $\mathrm{pH}$ is good for $\mathrm{Cr}(\mathrm{VI})$ removal by $\mathrm{BFe}^{0} \mathrm{NPs}$, which is consistent with previous results [14,16,23]. Although $\mathrm{pH} 3.0$ also belongs to acidic condition, the $\mathrm{Cr}(\mathrm{VI})$ removal percentage remarkably decreased at this $\mathrm{pH}$ level. Moreover, the observed rate constant $(k)$ decreased dramatically with the increasing initial $\mathrm{pH}$, revealing the determinative role of solution $\mathrm{pH}$ in reaction between $\mathrm{Cr}(\mathrm{VI})$ and $\mathrm{BFe}^{0} \mathrm{NPs}$.

Kinetics of reaction between $\mathrm{Cr}(\mathrm{VI})$ and $\mathrm{Fe}^{0}$ in aquatic systems are generally described by pseudo first-order, first-order, zero-order, or even reaction order less than unity (see review by Gheju [9]). However, pseudo second-order models have been found to best describe both $\mathrm{Cr}(\mathrm{VI})$ reduction with $\mathrm{Fe}_{\mathrm{Fe}} \mathrm{Fe}_{2} \mathrm{O}_{3}$ core-shell nanowires [50], and the adsorption of As by montmorillonite-supported $\mathrm{Fe}^{0} \mathrm{NPs}$ [18]. Obviously, the results depend on the experimental conditions. Gould [51] studied $\mathrm{Cr}(\mathrm{VI})$ reduction with $\mathrm{Fe}^{0}$ over a variety of conditions, and found that $\mathrm{Cr}(\mathrm{VI})$ removal varied with the contents of $\mathrm{Cr}(\mathrm{VI})$ and $\mathrm{H}^{+}$, as well as specific surface area of $\mathrm{Fe}^{0}$. Our present findings on $\mathrm{Cr}(\mathrm{VI})$ reduction kinetics differ from Shi et al. [14,16], who found the removal of $\mathrm{Cr}$ (VI) by $\mathrm{BFe}^{0} \mathrm{NPs}$ fitted pseudo first-order reaction kinetics. The possible reason may be the bentonite/iron mass ratio (and the specific surface area). Shi et al. $[14,16]$ used $\mathrm{BFe}^{0} \mathrm{NPs}$ with a $50 \%$ bentonite mass fraction, but, in our study, the bentonite content was only $4 \%$. Furthermore, in the present study, leachate wastewater always showed lower $\mathrm{Cr}(\mathrm{VI})$ removal percentages than simulated wastewater, indicating there may be other factors influencing $\mathrm{Cr}(\mathrm{VI})$ reduction kinetics.

The main mechanisms of $\mathrm{Cr}(\mathrm{VI})$ reduction involve the capacity of $\mathrm{Fe}^{0}$ particles to serve as electron donor, as well as of $\mathrm{Fe}(\mathrm{II})$ generated as products of $\mathrm{Fe}^{0}$ particles corrosion [9]. Using XPS analysis, Zhang et al. [52] concluded $\mathrm{Cr}(\mathrm{VI})$ removal mechanisms by $\mathrm{Fe}^{0} \mathrm{NPs}$ as: (i) large surface area; (ii) a great number of active reaction sites; and (iii) fast electron transport from $\mathrm{Fe}^{0} / \mathrm{FeCr}_{2} \mathrm{O}_{4}$ to $\mathrm{Cr}(\mathrm{VI})$. $\mathrm{BFe}^{0} \mathrm{NPs}$ with a high mass ratio of $\mathrm{Fe}^{0}$ can provide more effective electron donors and active sites, compared to the same amount of $\mathrm{BFe}^{0} \mathrm{NPs}$ with a high content of bentonite. Furthermore, as the specific surface areas are generally higher for $\mathrm{Fe}^{0} \mathrm{NPs}$ than for bentonite [14], a high ratio of bentonite in $\mathrm{BFe}^{0} \mathrm{NPs}$ may lead to a low adsorption capacity. Taking these into account, $\mathrm{BFe}^{0} \mathrm{NPs}$ with $4 \%$ bentonite are applicable to eliminate $\mathrm{Cr}(\mathrm{VI})$ from both simulated wastewater and leachate wastewater. Undoubtedly, since the 
chemical compositions of actual wastewaters and polluted groundwater are generally complex and vary with environmental conditions, more attempts are needed to examine the applicability of support $\mathrm{Fe}^{0} \mathrm{NPs}$ for future remediation of $\mathrm{Cr}(\mathrm{VI})$ in aquatic systems under complex realistic conditions.

\section{Conclusions}

$\mathrm{BFe}^{0} \mathrm{NPs}$ with different bentonite contents were synthesized and characterized using SEM and XRD techniques. $\mathrm{Fe}^{0}$ particles at nano-scales were found to disperse on the bentonite, which probably leads to less aggregation and greater stability of $\mathrm{Fe}^{0} \mathrm{NPs}$. Batch experiments were carried out to study $\mathrm{Cr}(\mathrm{VI})$ removal from two wastewaters by the selected $\mathrm{BFe}^{0} \mathrm{NPs}$ with $4 \%$ of bentonite at different $\mathrm{pH}$ values, reaction times, and $\mathrm{BFe}^{0} \mathrm{NPs}$ dosage levels. Results show that a low solution $\mathrm{pH}$ value (2.0) favored $\mathrm{Cr}(\mathrm{VI})$ removal. $\mathrm{Cr}(\mathrm{VI})$ was $100 \%$ removed from simulated wastewater and $90 \%$ from leachate wastewater when the $\mathrm{pH}$ value was 2.0 , but decreased significantly with increasing $\mathrm{pH}$ value. The $\mathrm{Cr}(\mathrm{VI})$ removal by $\mathrm{BFe}^{0} \mathrm{NPs}$ was very fast initially, and at least $85 \%$ of $\mathrm{Cr}(\mathrm{VI})$ was removed within $10 \mathrm{~min}$. Increase in $\mathrm{BFe}^{0} \mathrm{NPs}$ dosage led to increased $\mathrm{Cr}(\mathrm{VI})$ removal, and a dosage of $60 \mathrm{mg} \mathrm{BFe}{ }^{0} \mathrm{NPs}$ was effective for remediation of $\mathrm{Cr}(\mathrm{VI})$ wastewater. $\mathrm{Cr}(\mathrm{VI})$ removal by $\mathrm{BFe}^{0} \mathrm{NPs}$ fitted the pseudo second-order kinetic model. The removal percentages of $\mathrm{Cr}(\mathrm{VI})$ by $\mathrm{BFe} \mathrm{e}^{0} \mathrm{NPs}$ were generally higher in simulated wastewater than in leachates wastewater, but all approached 100\% at the optimal reaction conditions. Our results suggest that $\mathrm{BFe}^{0} \mathrm{NPs}$ with $4 \%$ bentonite could be effective for remediation of $\mathrm{Cr}(\mathrm{VI})$-bearing wastewaters. Furthermore, more work needs to be conducted to better characterize the morphology of the nanostructures and to illustrate the mechanisms involved in $\mathrm{Cr}$ (VI) removal.

Author Contributions: F.W. and W.Y. wrote the manuscript. Y.S. designed the study. W.Y. and F.Z. carried out the analyses. All authors approved the final version of the manuscript.

Funding: This study was financed by the National Natural Science Foundation of China (41471395), the National Natural Science Foundation of Shandong Province (ZR2018MD006), and the Doctoral Foundation of QUST (0100229003).

Acknowledgments: We thank the three anonymous reviewers and academic editor for their efforts in improving the manuscript.

Conflicts of Interest: The authors declare no conflict of interest.

\section{References}

1. Loyaux-Lawniczak, S.; Lecomte, P.; Ehrhardt, J.J. Behavior of hexavalent chromium in a polluted groundwater: Redox processes and immobilization in soils. Environ. Sci. Technol. 2001, 35, 1350-1357. [CrossRef] [PubMed]

2. Dhal, B.; Thatoi, H.N.; Das, N.N.; Pandey, B.D. Chemical and microbial remediation of hexavalent chromium from contaminated soil and mining/metallurgical solid waste: A review. J. Hazard. Mater. 2013, 250-251, 272-291.

3. Saha, R.; Nandi, R.; Saha, B. Sources and toxicity of hexavalent chromium. J. Coord. Chem. 2011, 64, $1782-1806$. [CrossRef]

4. Flora, S.D.; Wetterhahn, K.E. Mechanism of chromium (VI) metabolism and genotoxicity. Life Chem. Rep. 1989, 7, 169-244.

5. Dayan, A.D.; Paine, A.J. Mechanisms of chromium toxicity, carcinogenicity and allergenicity: Review of the literature from 1985 to 2000. Hum. Exp. Toxicol. 2001, 20, 439-451. [CrossRef] [PubMed]

6. Johnson, B.L.; DeRosa, C.T. Chemical mixtures released from hazardous waste sites: Implications for health risk assessment. Toxicology 1995, 105, 145-156. [CrossRef]

7. Fu, F.; Dionysiou, D.D.; Liu, H. The use of zero-valent iron for groundwater remediation and wastewater treatment: A review. J. Hazard. Mater. 2014, 267, 194-205. [CrossRef] [PubMed]

8. Li, X.; Elliott, D.W.; Zhang, W. Zero-valent iron nanoparticles for abatement of environmental pollutants: Materials and engineering aspects. Crit. Rev. Solid State Mater. Sci. 2006, 31, 111-122. [CrossRef]

9. Gheju, M. Hexavalent chromium reduction with zero-valent iron (ZVI) in aquatic systems. Water Air Soil Pollut. 2011, 222, 103-148. [CrossRef] 
10. Guan, X.; Sun, Y.; Qin, H.; Li, J.; Lo, I.M.; He, D.; Dong, H. The limitations of applying zero-valent iron technology in contaminants sequestration and the corresponding countermeasures: The development in zero-valent iron technology in the last two decades (1994-2014). Water Res. 2015, 75, 224-248. [CrossRef] [PubMed]

11. Zou, Y.; Wang, X.; Khan, A.; Wang, P.; Liu, Y.; Alsaedi, A.; Hayat, T.; Wang, X. Environmental remediation and application of nanoscale zero-valent iron and its composites for the removal of heavy metal ions: A review. Environ. Sci. Technol. 2016, 50, 7290-7304. [CrossRef] [PubMed]

12. Ponder, S.M.; Darab, J.G.; Mallouk, T.E. Remediation of $\mathrm{Cr}(\mathrm{VI})$ and $\mathrm{Pb}(\mathrm{II})$ aqueous solutions using supported, nanoscale zero-valent iron. Environ. Sci. Technol. 2000, 34, 2564-2569. [CrossRef]

13. Vinod, V.T.P.; Wacławek, S.; Senan, C.; Kupčík, J.; Pešková, K.; Černík, M.; Somashekarappa, H.M. Gum karaya (Sterculia urens) stabilized zero-valent iron nanoparticles: Characterization and applications for the removal of chromium and volatile organic pollutants from water. RSC Adv. 2017, 7, 13997-14009. [CrossRef]

14. Shi, L.N.; Zhang, X.; Chen, Z.L. Removal of chromium (VI) from wastewater using bentonite-supported nanoscale zero-valent iron. Water Res. 2011, 45, 886-892. [CrossRef] [PubMed]

15. Li, Y.; Li, J.; Zhang, Y. Mechanism insights into enhanced $\mathrm{Cr}(\mathrm{VI})$ removal using nanoscale zerovalent iron supported on the pillared bentonite by macroscopic and spectroscopic studies. J. Hazard. Mater. 2012, 227-228, 211-218. [CrossRef] [PubMed]

16. Shi, L.N.; Lin, Y.M.; Zhang, X.; Chen, Z.L. Synthesis, characterization and kinetics of bentonite supported nZVI for the removal of $\mathrm{Cr}(\mathrm{VI})$ from aqueous solution. Chem. Eng. J. 2011, 171, 612-617. [CrossRef]

17. Li, Z.; Jones, H.K.; Bowman, R.S.; Helferich, R. Enhanced reduction of chromate and PCE by pelletized surfactant-modified zeolite/zerovalent iron. Environ. Sci. Technol. 1999, 33, 4326-4330. [CrossRef]

18. Bhowmick, S.; Chakraborty, S.; Mondal, P.; Renterghem, W.V.; Berghe, S.V.D.; Roman-Ross, G.; Chatterjee, D.; Iglesias, M. Montmorillonite-supported nanoscale zero-valent iron for removal of arsenic from aqueous solution: Kinetics and mechanism. Chem. Eng. J. 2014, 243, 14-23. [CrossRef]

19. Liu, T.; Wang, Z.L.; Yan, X.; Zhang, B. Removal of mercury (II) and chromium (VI) from wastewater using a new and effective composite: Pumice-supported nanoscale zero-valent iron. Chem. Eng. J. 2014, 245, 34-40. [CrossRef]

20. Üzüm, Ç.; Shahwan, T.; Eroğlu, A.E. Synthesis and characterization of kaolinite-supported zero-valent iron nanoparticles and their application for the removal of aqueous $\mathrm{Cu}$ and Co ions. Appl. Clay Sci. 2009, 43, 172-181. [CrossRef]

21. Fu, R.; Yang, Y.; Xu, Z.; Zhang, X.; Guo, X.; Bi, D. The removal of chromium (VI) and lead (II) from groundwater using sepiolite-supported nanoscale zero-valent iron (S-NZVI). Chemosphere 2015, 138, 726-734. [CrossRef] [PubMed]

22. Liu, T.; Zhao, L.; Sun, D.; Tan, X. Entrapment of nanoscale zero-valent iron in chitosan beads for hexavalent chromium removal from wastewater. J. Hazard. Mater. 2010, 184, 724-730. [CrossRef] [PubMed]

23. Geng, B.; Jin, Z.; Li, T.; Qi, X. Kinetics of hexavalent chromium removal from water by chitosan-Fe nanoparticles. Chemosphere 2009, 75, 825-830. [CrossRef] [PubMed]

24. Hoch, L.B.; Mack, E.J.; Hydutsky, B.W.; Hershman, J.M.; Skluzacek, J.M.; Mallouk, T.E. Carbothermal synthesis of carbon-supported nanoscale zero-valent iron particles for the remediation of hexavalent chromium. Environ. Sci. Technol. 2008, 42, 2600-2605. [CrossRef] [PubMed]

25. Dai, Y.; Hu, Y.; Jiang, B.; Zou, J.; Tian, G.; Fu, H. Carbothermal synthesis of ordered mesoporous carbon-supported nano zero-valent iron with enhanced stability and activity for hexavalent chromium reduction. J. Hazard. Mater. 2016, 309, 249-258. [CrossRef] [PubMed]

26. Dong, H.; Deng, J.; Xie, Y.; Zhang, C.; Jiang, Z.; Cheng, Y.; Hou, K.; Zeng, G. Stabilization of nanoscale zero-valent iron (nZVI) with modified biochar for $\mathrm{Cr}(\mathrm{VI})$ removal from aqueous solution. J. Hazard. Mater. 2017, 332, 79-86. [CrossRef] [PubMed]

27. Zhu, Y.; Li, H.; Zhang, G.; Meng, F.; Li, L.; Wu, S. Removal of hexavalent chromium from aqueous solution by different surface-modified biochars: Acid washing, nanoscale zero-valent iron and ferric iron loading. Bioresour. Technol. 2018, 261, 142-150. [CrossRef] [PubMed]

28. Qian, L.; Zhang, W.; Yan, J.; Han, L.; Chen, Y.; Ouyang, D.; Chen, M. Nanoscale zero-valent iron supported by biochars produced at different temperatures: Synthesis mechanism and effect on $\mathrm{Cr}(\mathrm{VI})$ removal. Environ. Pollut. 2017, 223, 153-160. [CrossRef] [PubMed] 
29. Fu, R.; Zhang, X.; Xu, Z.; Guo, X.; Bi, D.; Zhang, W. Fast and highly efficient removal of chromium (VI) using humus-supported nanoscale zero-valent iron: Influencing factors, kinetics and mechanism. Sep. Purif. Technol. 2016, 174, 362-371. [CrossRef]

30. Liu, J.; Mwamulima, T.; Wang, Y.; Fang, Y.; Song, S.; Peng, C. Removal of Pb(II) and Cr(VI) from aqueous solutions using the fly ash-based adsorbent material-supported zero-valent iron. J. Mol. Liq. 2017, 243, 205-211. [CrossRef]

31. Peng, Z.; Xiong, C.; Wang, W.; Tan, F.; Xu, Y.; Wang, X.; Qiao, X. Facile modification of nanoscale zero-valent iron with high stability for Cr(VI) remediation. Sci. Total Environ. 2017, 596-597, 266-273. [CrossRef] [PubMed]

32. Sheng, G.; Hu, J.; Li, H.; Li, J.; Huang, Y. Enhanced sequestration of Cr(VI) by nanoscale zero-valent iron supported on layered double hydroxide by batch and XAFS study. Chemosphere 2016, 148, 227-232. [CrossRef] [PubMed]

33. Xu, C.; Yang, W.; Liu, W.; Sun, H.; Jiao, C.; Lin, A.J. Performance and mechanism of Cr(VI) removal by zero-valent iron loaded onto expanded graphite. J. Environ. Sci. 2018, 67, 14-22. [CrossRef] [PubMed]

34. Hu, B.; Chen, G.; Jin, C.; Hu, J.; Huang, C.; Jiang, S.; Sheng, G.; Ma, J.; Huang, Y. Macroscopic and spectroscopic studies of the enhanced scavenging of $\mathrm{Cr}(\mathrm{VI})$ and $\mathrm{Se}(\mathrm{VI})$ from water by titanate nanotube anchored nanoscale zero-valent iron. J. Hazard. Mater. 2017, 336, 214-221. [CrossRef] [PubMed]

35. Lv, X.; Xue, X.; Jiang, G.; Wu, D.; Sheng, T.; Zhou, H.; Xu, X. Nanoscale zero-valent iron (nZVI) assembled on magnetic $\mathrm{Fe}_{3} \mathrm{O}_{4}$ /graphene for chromium (VI) removal from aqueous solution. J. Colloid Interface Sci. 2014, 417, 51-59. [CrossRef] [PubMed]

36. Lv, X.; Zhang, Y.; Fu, W.; Cao, J.; Zhang, J.; Ma, H.; Jiang, G. Zero-valent iron nanoparticles embedded into reduced graphene oxide-alginate beads for efficient chromium (VI) removal. J. Colloid Interface Sci. 2017, 506, 633-643. [CrossRef] [PubMed]

37. Bailey, S.E.; Olin, T.J.; Bricka, R.M.; Adrian, D.D. A review of potentially low-cost sorbents for heavy metals. Water Res. 1999, 33, 2469-2479. [CrossRef]

38. Lv, X.; Hu, Y.; Tang, J.; Sheng, T.; Jiang, G.; Xu, X. Effects of co-existing ions and natural organic matter on removal of chromium (VI) from aqueous solution by nanoscale zero valent iron (nZVI)- $\mathrm{Fe}_{3} \mathrm{O}_{4}$ nanocomposites. Chem. Eng. J. 2013, 218, 55-64. [CrossRef]

39. Liu, C.; Côté, R.P. Controlling chromium slag pollution utilising scavengers: A case of Shandong Province, China. Waste Manag. Res. 2015, 33, 363-369. [CrossRef] [PubMed]

40. Homaeigohar, S.; Zillohu, A.U.; Abdelaziz, R.; Hedayati, M.K.; Elbahri, M. A novel nanohybrid nanofibrous adsorbent for water purification from dye pollutants. Materials 2016, 9, 848. [CrossRef] [PubMed]

41. Lee, T.; Lim, H.; Lee, Y.; Park, J.W. Use of waste iron metal for removal of Cr(VI) from water. Chemosphere 2003, 53, 479-485. [CrossRef]

42. Yuan, P.; Fan, M.; Yang, D.; He, H.; Liu, D.; Yuan, A.; Zhu, J.; Chen, T. Montmorillonite-supported magnetite nanoparticles for the removal of hexavalent chromium $[\mathrm{Cr}(\mathrm{VI})]$ from aqueous solutions. J. Hazard. Mater. 2009, 166, 821-829. [CrossRef] [PubMed]

43. Su, C.; Puls, R.W. Arsenate and arsenite removal by zerovalent iron: effects of phosphate, silicate, carbonate, borate, sulfate, chromate, molybdate, and nitrate, relative to chloride. Environ. Sci. Technol. 2001, 35, 4562-4568. [CrossRef] [PubMed]

44. Tanboonchuy, V.; Grisdanurak, N.; Liao, C.H. Background species effect on aqueous arsenic removal by nano zero-valent iron using fractional factorial design. J. Hazard. Mater. 2012, 205-206, 40-46. [CrossRef] [PubMed]

45. Yin, W.; Wu, J.; Li, P.; Wang, X.; Zhu, N.; Wu, P.; Yang, B. Experimental study of zero-valent iron induced nitrobenzene reduction in groundwater: The effects of $\mathrm{pH}$, iron dosage, oxygen and common dissolved anions. Chem. Eng. J. 2012, 184, 198-204. [CrossRef]

46. Singh, R.; Misra, V.; Singh, R.P. Synthesis, characterization and role of zero-valent iron nanoparticle in removal of hexavalent chromium from chromium-spiked soil. J. Nanopart. Res. 2011, 13, 4063-4073. [CrossRef]

47. Manning, B.A.; Kiser, J.R.; Kwon, H.; Kanel, S.R. Spectroscopic investigation of Cr(III)- and Cr(VI)-treated nanoscale zerovalent iron. Environ. Sci. Technol. 2007, 41, 586-592. [CrossRef] [PubMed]

48. Boparai, H.K.; Joseph, M.; O'Carroll, D.M. Kinetics and thermodynamics of cadmium ion removal by adsorption onto nano zerovalent iron particles. J. Hazard. Mater. 2011, 186, 458-465. [CrossRef] [PubMed] 
49. Ho, Y.S.; Mckay, G. The kinetics of sorption of divalent metal ions onto sphagnum moss peat. Water Res. 2000, 34, 735-742. [CrossRef]

50. Ai, Z.; Cheng, Y.; Zhang, L.; Qiu, J. Efficient removal of $\mathrm{Cr}(\mathrm{VI})$ from aqueous solution with $\mathrm{Fe}_{\mathrm{O}} \mathrm{Fe}_{2} \mathrm{O}_{3}$ core-shell nanowires. Environ. Sci. Technol. 2008, 42, 6955-6960. [CrossRef] [PubMed]

51. Gould, J.P. The kinetics of hexavalent chromium reduction by metallic iron. Water Res. 1982, 16, $871-877$. [CrossRef]

52. Zhang, S.H.; Wu, M.F.; Tang, T.T.; Xing, Q.J.; Peng, C.Q.; Li, F.; Liu, H.; Luo, X.B.; Zou, J.P.; Min, X.B.; et al. Mechanism investigation of anoxic $\mathrm{Cr}(\mathrm{VI})$ removal by nano zero-valent iron based on XPS analysis in time scale. Chem. Eng. J. 2018, 335, 945-953. [CrossRef]

(C) 2018 by the authors. Licensee MDPI, Basel, Switzerland. This article is an open access article distributed under the terms and conditions of the Creative Commons Attribution (CC BY) license (http://creativecommons.org/licenses/by/4.0/). 